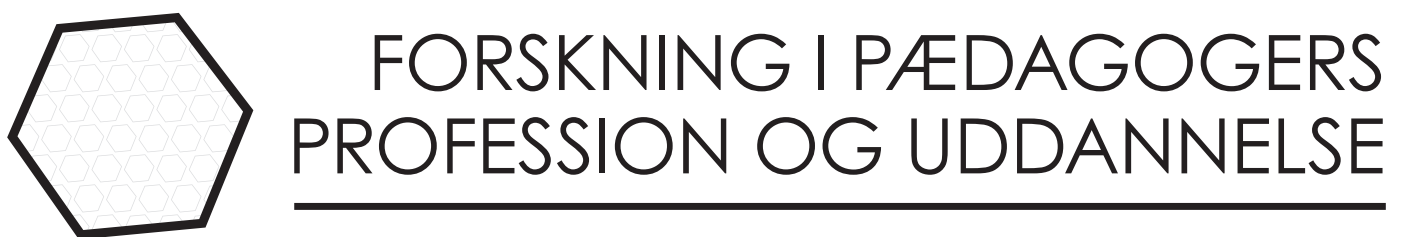

\title{
Et kontinuum over børn og unges deltagelsesformer
}

\section{Maria Bruselius-Jensen}

Ph.d., Lektor, Center for Ungdomsforskning, Aalborg Universitet mariabj@hum.aau.dk 


\title{
Resume
}

Denne artikel sætter fokus på, hvordan den pædagogiske facilitering af deltagelsesprocesser er stærkt definerende for børn og unges mulighed for, og deres oplevelse af, at have indflydelse på forhold, som er betydningsfulde for dem.

Artiklen præsenterer en dynamisk teori- og empiriinformeret forståelsesramme for børn og unges deltagelse: et deltagelseskontinuum. Forståelsesrammen er udformet på baggrund af et bredt empirisk arbejde med både børn og unge samt professionelle engageret $\mathrm{i}$ deltagelsesprojekter på mange forskellige arenaer. På den baggrund er det kapitlets hensigt at bidrage til at styrke og tydeliggøre valget af metoder og tilgange i det kontinuerlige pædagogiske arbejde med at rammesætte børn og unges deltagelsesmuligheder. Forståelsesrammen tydeliggør den store spændvidde af indsatser, som benyttes af professionelle i forskellige kontekster. Ved at fremhæve med hvilken tydelighed, eller utydelighed, deltagelsens forandringsskabende potentiale fremstår, anlægger modellen samtidig også et børn- og ungeperspektiv, som tydeliggør børn og unges egne oplevelser af, hvornår deltagelse i beslutnings- og forandringsprocesser opleves som meningsfulde for dem.

\begin{abstract}
A continuum on young people's forms of participation

This article discusses how the pedagogical facilitation of children and young people's participation is highly defining for their access to and perception of being able to affect conditions of importance for their everyday life. By introducing a new framework, the chapter aims to make the impact of professionally chosen methods and approaches more transparent in order to qualify pedagogical endeavors to facilitate young people's participation.

The article presents a dynamic, empirically, and theoretically informed framework to determine young people's forms of participation: A continuum of participation. The framework is based on extensive fieldwork with both young people and professionals engaged in work to promote young people's access to participation in a range of contexts and arenas. It makes the multitudinous forms of participation applied by professionals to facilitate young people's participation stand more transparent. But most importantly, the continuum adopts a young people's perspective by visually implying when young people themselves most distinctly experience to have a voice and access to make changes through their participation, but likewise, when their participation is blurred or becomes invisible.
\end{abstract}

\section{Nøgleord}

Unge, deltagelse, deltagelsesmodel, pædagogisk arbejde, medbestemmelse.

\section{Keywords}

Young people, participation, framework of participation, educational approaches, co-decision. 


\section{Introduktion}

I disse år fejres 30-året for ratificeringen af FN’s børnekonvention og ønsket om at fremme børn og unges deltagelsesmuligheder står som en helt central målsætning i næsten alle hjørner af civilsamfundet (Bruselius-Jensen \& Nielsen 2020; Walther et al, 2019). Men målsætningen står særligt centralt i det pædagogiske arbejde, nærmest som et reason d'etre i arbejdet med unge (Warming, 2011, Walsh \& Black, 2018). I deres hyppigt refererede værk fra 1989 beskriver James, Jenks \& Prout (1989), hvordan børn og unge ikke længere kun forstås som objekter for voksnes målsætninger og opdragelse, men i stigende grad forstås og inddrages som kompetente væsner i deres egen ret. Informeret af dette børne- og ungesyn har forskere og professionelle fra multiple arenaer arbejdet med at udvikle metoder til at facilitere børn og unges adgang til at have indflydelse på forhold, som de tillægger betydning i deres hverdagsliv (Pohl et al, 2019; Baraldi \& Cockburn; 2018, Percy-Smith \& Thomas, 2009). Dette arbejde er pågående og reflekterer, at der stadig hersker usikkerhed om hvordan børn og unge bedst muligt og mest meningsfuldt kan deltage. En del af denne usikkerhed bunder ikke mindst i, at der er multiple forståelser af, hvad der forstås ved børn og unges deltagelse (Warming, 2019). Forståelser, som ændrer sig i takt med at ungdomslivets betingelser og vores børne-ungesyn ændrer sig og at nye aktører og arenaer engagerer sig i inddragelsesarbejdet (Bruselius-Jensen, Pitti \& Tisdall, 2021). På den baggrund er det dette kapitels ærinde at introducere en forståelsesramme, som udmærker sig ved at være særligt informeret af et børne-ungeperspektiv og som dermed tydeliggør, hvordan deltagelsen opleves af og tydeliggøres for de deltagende børn og unge. En model, som kan udgøre en systematisk visualiseret refleksionsramme for det pædagogiske arbejde med at facilitere børn og unges deltagelse.

\section{Empirisk grundlag for studiet og kontinuummet}

Artiklen trækker på et omfattende studie, som har fulgt seks konkrete indsatser (se tabel 1), der alle har fokuseret på at udvikle og afprøve metoder til at fremme børn og unges deltagelsesmuligheder i en række forskellige kontekster (Bruselius-Jensen og Nielsen, 2020).

Indsatserne har meget forskellig karakter og tilgange. Dog har de alle karakter af 'projekter', med en afgrænset tidshorisont og prædefinerede mål, ligesom alle projekter har fokus på børn og unge i særligt sårbare og udsatte positioner. Bredden i erfaringerne fra projekterne gør studiets konklusioner generelt anvendelige i pædagogisk arbejde. 


\begin{tabular}{|c|c|}
\hline Viden Viser Vej ${ }^{1}$ & $\begin{array}{l}\text { Et initiativ fra Børne- og Ungdomspsykiatrien i Region Syddanmark, } \\
\text { som udvikler metoder til at inddrage de unge brugere i udviklingspro- } \\
\text { jekter i psykiatrien. }\end{array}$ \\
\hline Tabeboblen ${ }^{2}$ & $\begin{array}{l}\text { Et projekt udført af Psykiatrifonden, som udvikler og implementer } \\
\text { et samtaleværktøj til familier med forældre i behandling for psykisk } \\
\text { sygdom. }\end{array}$ \\
\hline Rettighedsskoler ${ }^{3}$ & $\begin{array}{l}\text { En indsats drevet af UNICEF Danmark, som implementerer et rettig- } \\
\text { hedskoncept på en lang række danske grundskoler. }\end{array}$ \\
\hline Mægling i børnehøjde ${ }^{4}$ & $\begin{array}{l}\text { Et koncept udviklet af KFUM Socialt Arbejde, som muliggør, at børn } \\
\text { kan deltage i familiens konfliktmægling. }\end{array}$ \\
\hline Børnedemokrati ${ }^{5}$ & $\begin{array}{l}\text { Et samarbejde mellem Konradi og AKB Milestedet, som udvikler et } \\
\text { koncept til at etablere børnebestyrelser i almene boligområder. }\end{array}$ \\
\hline Alle med i fællesskabet ${ }^{6}$ & $\begin{array}{l}\text { Mellemfolkeligt Samvirkes indsats, som arbejder med at styrke delta- } \\
\text { gelsesmulighederne for unge i en række såkaldt 'udsatte boligområ- } \\
\text { der'. }\end{array}$ \\
\hline
\end{tabular}

Tabel 1 Oversigt over projekter som indgår $i$ studiet

Grundet indsatsernes meget forskellige formater har studiet benyttet en flerhed af metoder. For alle projekter har både de deltagende børn og unge samt de professionelle bidraget til dataindsamling. Data omfatter således kvalitative interviews og journey maps (Bruselius-Jensen \& Nielsen, 2021) med 111 børn og unge samt interviews med 45 forskellige professionelle. Dataindsamling og metodeovervejelser er yderligere udfoldet i Bruselius-Jensen og Nielsen (2020), ligesom der også her er en mere detaljeret beskrivelse af de seks projekter. Kontinuummet og de dataanalyser, som præsenteres i denne artikel, er dels informeret af de teoretiske kilder refereret i denne artikel, men også i særdeleshed på baggrund af empiriske udsagn fra de mange respondenter i studiet. Det er studiet i sin helhed, som udgør grundlaget for kontinuummet. De empiriske eksempler, som præsenteres i dette studie, er således repræsentative for det samlede studie.

\section{Forståelsesrammer for børn og unges deltagelse}

Harts' (1992) 'deltagelsesstige' udgør en central reference for definitioner af børn og unges deltagelse. Stigen er en videreudvikling af Arnsteins (1969) 'medborgerskabsstige', men Hart sætter eksplicit fokus på de mange forskellige grader af inddragelse, som børn og unges deltagelse i beslutnings- og forandringsprocesser dækker over. Stigens otte trin definerer således børn og unges deltagelse efter deres indflydelsesgrad: Fra ringe deltagelse, hvor de hverken initierer eller

1 http://psykiatrienisyddanmark.dk/wm511015

2 https://www.psykiatrifonden.dk/media/1418935/snak-sammen-samtalebog-endelig.pdf

3 https://rettighedsskoler.unicef.dk

4 https://www.kfumsoc.dk/projekter/konfliktmaegling

5 http://børnedemokrati.dk

6 https://www.ms.dk/arbejde/danmark/unge-udsatte/mere 
medvirker i beslutninger, hos Hart defineret som 'ikke-deltagelse', til en stærk og selvinitieret deltagelse, i sidste ende understøttet af involverede voksne. Deltagelsesstigen synliggør også, at deltagelse er en relationel proces mellem børn og voksne og skærper derfor opmærksomheden på balancegangen mellem voksne eller børn som de vidende og magtfulde i deltagelsesprocesser. I en dansk kontekst har blandt andet Tofteng og Bladt (2019) ladet sig inspirere af Harts deltagelsesstige i deres model for deltagelse "Upturned participation" (Tofteng og Bladt 2019. p. 119). I lighed med Hart sætter de med deres 'omvendte deltagelse' fokus på om det er børn og unge eller professionelle og andre voksne, som tager initiativ til, driver og bestemmer indholdet i planlægningsprocesser i det sociale arbejde. Dette perspektiv sætter fokus på et kerneforhold i fremme af børn og unges deltagelse, nemlig, at børn og unge, grundet deres begrænsede erfaring, uddannelse, økonomiske ressourcer og adgang til netværk og indflydelse, er i et latent ulighedsforhold til voksne og at faciliteringen af deltagelse derfor, i sin essens, handler om at øge børn og unges adgang til ressourcer og andre forhold, som kan fremme deres deltagelsesmuligheder (Bruselius-Jensen og Nielsen, 2020; Batsleer et al, 2017).

Mens 'deltagelsesstigen' har været og stadig er en vigtig inspirationskilde for udviklingen af både praksis og forskning, har den også været afsæt for en lang række - også kritiske - modificeringer i relation til børn og unges deltagelse. Hovedparten af kritikken har fokus på stigens hierarkiseringer af forskellige deltagelsesformer (Jensen \& Simovska, 2005) og er båret af forståelser af børn og unges deltagelse som en fundamentalt relationel frem for hierarkisk proces (Mannion, 2007). Wyness (2019) beskriver, hvordan man med 70'ernes kritisk teoretiske inspiration argumenterede for at friscette børn og unge til at styre og udvikle deres eget liv og hvordan denne forståelse nu er nuanceret med en erkendelse af, at alle udviklings- og forandringsprocesser pågår i et samspil med voksne og professionelle. Fokus på det relationelle er også central i tilgange, som forstår deltagelsesprocesser som sociale loereprocesser. Percy-Smith (2006) definerer således en model for "A communicative action space" (Percy-Smith 2006, p. 169), hvor deltagelse forstås som ligeværdige dialogiske processer mellem børn og unge og andre aktører, hvorigennem alle parter lærer af hinanden. En fundamental demokratiserende orientering, som Tofteng og Bladt (2019) også skriver sig ind i.

Mens disse tilgange på forskellig vis har deres fokus på deltagelsesprocesser, hvor børn og unge er aktive, synlige deltagere med forskellige grader af indflydelse, bidrager Warming (2011) til at udvide forståelsen af deltagelse ved at fremhæve, at børn og unges deltagelse også kan antage mere indirekte former. Hun skelner mellem, at børn og unge deltager ved at ytre deres egne "Indefra-perspektiver", men inkluderer også mere indirekte deltagelsesformer, hvor voksne repræsenterer børn og unge, og via et "tilstræbt indefra-perspektiv (..) forsøger at sætte sig i barnets sted" (Warming, 2011, p 18). Det kan være situationer, hvor børn og unge enten ikke selv får adgang, har mulighed eller lyst til at deltage, og hvor voksne repræsenterer deres synspunkter. Denne deltagelsesform er næsten altid 
til stede i processer, som faciliterer børn og unges deltagelse og udgør dermed yderligere en dimension i deltagelsesformernes kontinuum.

\section{Et kontinuum over børn og unges deltagelse}

I samspil med data fra studiet og ovenstående teoretiske perspektiver tegner der sig et kontinuum over børn og unges deltagelsesformer, som kan visualiseres således:

\section{Et kontinuum over børn og unges deltagelsesformer}

\section{0}

\begin{tabular}{|c|c|c|}
\hline 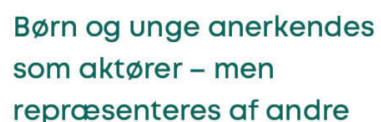 & $\begin{array}{l}\text { Børn og unge har } \\
\text { adgang til at ytre sig }\end{array}$ & $\begin{array}{l}\text { Børn og unge har } \\
\text { adgang til at skabe } \\
\text { ønsket forandring }\end{array}$ \\
\hline
\end{tabular}

Figur 1 Figuren er udviklet $i$ samarbejde med Anne Mette W. Nielsen og publiceret første gang i Bruselius-Jensen, $M \&$ Nielsen, Anne Mette W. (2020).

Der er tale om et kontinuum, som illustrerer de mange forskellige former, børn og unges deltagelse kan antage, ved angivelse af tre deltagelsesgrundformer og indikation af, at der mellem disse tre punkter falder en række forskellige variationer af deltagelsesformer. Mens Harts deltagelsesformer er illustreret som hierarkiske trin på en stige, så betoner dette kontinuum, at børn og unges deltagelse ofte kan variere gennem et projektforløb og gradvist ændre sig i mere glidende overgange. I forlængelse af Wyness (2019) og Percy-Smith (2006) tager dette kontinuum desuden højde for voksnes allestedsnærværende rolle som facilitatorer af børn og unges muligheder for deltagelse. Mens både Hart (1996) og Tofteng og Bladt (2019) har et stærkt fokus på rollefordelingen mellem unge og voksne, så sætter kontinuummet fokus på den tydelighed og relevans, hvormed børn og unge oplever sig selv som aktører i udviklings- og forandringsprocesser. Den skalerede farvelægning understreger desuden, hvordan børn og unge træder tydeligere og tydeligere frem som deltagere, både for sig selv og for professionelle og andre voksne, jo længere deltagelsesformen bevæger sig mod kontinuummets højre akse.

Det første punkt angiver, hvordan deltagelse kan bestå i, at børn og unges perspektiver repræsenteres af andre. Punktet er udviklet med reference til det, Warming (2011) definerer som et tilstræbt indefra-perspektiv. I denne deltagelsesform anerkendes børn og unge som aktører, men de har af forskellige årsager ikke direkte adgang til at deltage og ytre sig. I vores studie benyttes denne deltagelsesform meget ofte og med stor selvfølgelighed af professionelle i planlægning og forandringsprocesser, som skal fremme børn og unges deltagelse. Og selv om det 
i mange tilfælde omfatter professionelles formidling af børn- og ungeperspektiver, som er fremkommet gennem deltagelsen i en pågående udviklingsproces, så er det ofte skjult for børn og unge, at deres perspektiver fremlægges i andre fora eller bidrager til udvikling af metoder eller planer.

Det andet punkt, midt for i kontinuummet, angiver, hvordan deltagelsesformer kan bestå i at børn og unge får adgang til at ytre sig i forskellige forhold, som har betydning for deres hverdagsliv. I denne deltagelsesform har de mulighed for at give deres meninger til kende, men har ikke selv defineret problemstillinger, ligesom deres ytringer ikke nødvendigvis leder til konkrete forandringer. Denne deltagelsesform figurerer lavt på Hart's stige, med betegnelsen 'konsultation'. Men data fra vores undersøgelse viser, at oplevelsen af at blive hørt og taget alvorligt i sig selv har stor betydning for de deltagende børn og unge, hvilket understreger, at selve deltagelsens relationelle karakter og at det i sig selv at have gode dialoger med voksne, kan opleves som meningsfuld deltagelse for børnene selv.

Det tredje punkt angiver, hvordan deltagelsesformer kan bestå i, at børn og unge både får mulighed for at definere problemstillinger og at deltage i at skabe konkrete forandringer. I denne deltagelsesform har de både mulighed for at ytre sig og for at gøre en tydelig forskel for sig selv og for andre. I studiet har synligheden af deltagelsens forandringsskabende potentiale haft stor betydning for de børn, som har haft adgang til denne deltagelsesform. Denne iagttagelse understeger, at deltagelsen fremstår med størst meningsfuldhed hos børn og unge, når de oplever, at den er forandringsskabende for dem selv og for andre.

Intentionen med kontinuummet er at skabe opmærksomhed på deltagelsens processuelle karakter og multiple former. Det udfoldes i de følgende afsnit, hvor det tillige synliggøres, at der ikke tale om en hierarkisk fordeling, idet alle deltagelsesformerne kan have deres berettigelse i forskellige kontekster og led i processen og med forskellige børn og unge. Samtidig understreges, hvordan en tydelighed omkring valg af deltagelsesformer kan styrke de pædagogiske valg og muliggøre, at deltagelsen og betydningen heraf træder tydeligst muligt frem for børn og unge.

\section{Deltagelsens ikke-hierarkiske og foranderlige form}

Kontinuummet tydeliggør deltagelsens processuelle karakter og hvordan deltagelsesformerne kan spænde fra den ene yderlighed af kontinuummet til den anden inden for den samme udviklingsproces, og endda inden for den samme mikroproces, med børn og unge.

Region Syddanmarks projekt, Viden Viser Vej, kan eksemplificere, hvordan børn og unges deltagelsesformer kan variere betragteligt inden for et projekt. Det konkrete omdrejningspunkt i projektet er udviklingen af et dialogværktøj i form af en applikation (app), rettet mod unge i ambulant behandling. I den første del af projektet deltog børn og unge primært som repræsenteret af de professionelle i projektledelsen, idet projektets målsætning blev formuleret med afsæt i erfaringer fra et tidligere projekt, hvor unge i psykiatrien var deltagere i den fysiske 
indretning af deres afdeling 7 . Erfaringer herfra informerede både metodevalg, ungeforståelse og til dels også problemidentifikationen for Viden Viser Vej. På et deltagelseskontinuum havde de unge deltagere fra det første projekt dermed indirekte indflydelse på form og formål i projektet, dog i en form, som var oversat af og udelukkende synligt for projektledelsen. Den første inddragelse bestod i en række idégenereringsværksteder med deltagelse af unge, forældre og behandlere, med det formål at udvikle løsninger til at styrke kommunikationen mellem behandlere og unge i ambulant behandling. En deltager fortæller:

\footnotetext{
"Det var sådan lidt moerkeligt, men det er jo rigtigt nok, for det er jo os, der er eksperterne. Det er jo ikke de overloeger, som har siddet på børne- og ungepsykiatrisk afdeling $i$ 10 år, som ikke rigtig ved noget, der er eksperter. De ved ikke, hvordan vi har det. De ved, hvordan de har skruet deres forskellige pakker sammen i deres pakkeforløb, men de ved ikke hvordan der er inde $i$ en af de pakker.

Så på den måde har det voret en meget positiv oplevelse."
}

Som det fremgår af citatet, oplevede de unge deltagere sig generelt lyttet til og taget alvorligt og oplevede at have mulighed for at ytre sig om forhold, som de ellers ikke oplever at blive hørt om og inddraget i i det psykiatriske behandlingssystem. Deltagelsesformen befinder sig altså midt på kontinuummet over deltagelsesformer. I den videre udvikling og realisering af app'en havde projektledelsen meget svært ved at inddrage unge, som stadig var i ambulantbehandling, da disse generelt ikke havde overskud til at deltage. I stedet valgte ledelsen at inddrage tre tidligere patienter som repræsentanter for de unge i ambulant behandling. Disse tre unge deltog i projektets styregruppe og i arbejdet med at udvikle det endelig kommunikationsværktøj. De oplevede deltagelsen som højst meningsfuld. Særligt deres medvirken i udviklingen af en helt konkret platform, med potentiale til at gøre en forskel for andre unge, havde stor betydning. En af de unge udtrykker det således;"Jeg har vœeret syg i rigtigt mange år, og det giver en ny mening for mig nu, hvor jeg kan bruge min erfaring til at hjoelpe andre, scrligt fordi vi kan dele vores historier." Deltagelse som genererer tydelige forandringer, også for andre unge, kan altså have overordentlig stor betydning for de unge. Som citatet udtrykker, kan det skabe en helt anden oplevelse af meningsfuldhed og aktørskab. Selv om muligheden for at gribe forandrende ind i betydningsfulde forhold er stærkest i kontinuummets højre side, så viser erfaringerne fra Viden Viser Vej, hvordan alle tre deltagelsesformer kan have deres berettigelse for forskellige unge og i forskellige led af processen.

Hvor deltagelsesformerne i Viden Viser Vej primært varierede gennem projektprocessen, så viser UNICEF's koncept til folkeskoler, Rettighedsskoler, at deltagelsen også parallelt kan antage forskellige former for de unge, som på forskellig vis er en del af projektet. Rettighedsskolekonceptet har til formål at styrke børn og unges viden om rettigheder, men også at understøtte praktiseringen af rettig-

7 http://www.psykiatrienisyddanmark.dk/wm472204 
heder på og uden for skolen. Konceptet henvender sig til hele den samlede elevgruppe gennem emneuger, oplysningsaktiviteter og til en vis grad ved integration i undervisningen. Men det er nedsættelsen af et Rettighedsråd, som skaber den tydeligste adgang til deltagelse i projektet. En Rettighedsrådselev fortæller: "Man har ret til at sige sin mening frit, man kan sige, hvad man synes om reglerne, hvordan det er, man kan lave om på det, snakke om det." På tværs af skolerne tydeliggør elevernes fortællinger, at deltagelse i Rettighedsrådet giver adgang til at have en stemme og blive lyttet til, men også at være medbestemmende i forhold, som knytter sig til dét at være Rettighedsskole. Herunder i nogle tilfælde at skabe konkrete forandringer i forhold, som eleverne oplever som betydningsfulde. For Rettighedsskole-eleverne ligger deltagelsen altså midt for og længst til højre på vores deltagelseskontinuum. De øvrige elever peger på, at de oplever at øge deres viden om rettigheder samt at konceptet giver adgang til momentvise oplevelser af deltagelse, når skolerne laver konkrete indsatser som et led i at være Rettighedsskole. For eksempel fortæller eleverne, at pandekagesalg til fordel for Børnetelefonen giver oplevelsen af at kunne gøre en forskel for andre børn. Samtidig oplever flere elever ikke øgede deltagelsesmuligheder forbundet med at være Rettighedsskole. I deres optik bliver konceptet mere et tomt løfte, som understreger deres generelle oplevelse af manglende indflydelsesmuligheder i skolen - ikke-deltagelse, som Hart (1992) ville klassificere det. En elev omtaler eksempelvis Rettighedsskolekonceptet som at få en gave og opdage, at den er tom. Rettighedsskoleprojektet viser på den måde, at samme indsats kan skabe meget forskellige adgange og oplevelser af deltagelse for eleverne alt efter, hvordan de positioneres som deltagere.

\section{Deltagelsens tydelighed for børn og unge}

Mens deltagelsesformerne ikke er hierarkisk ordnede, så angiver kontinuummet en hierarkiseret visualisering af, hvornår deltagelsen fremstår tydeligt for børn og unge selv.

Vores forskning er rig på eksempler, hvor deltagelsen enten er helt skjult eller meget utydeligt for børn og unge. Eksempelvis testede projektet Viden Viser Vej deres app på en gruppe unge $\mathrm{i}$ behandling. For at gøre testen så objektiv som muligt blev de unge ikke oplyst om, at de deltog i en afprøvning og at deres erfaringer ville indgå i den videre udviklingsproces. Ved et efterfølgende interview blev de unge glade for at høre, at de blev konsulteret og opfattede det som meget meningsfuldt, at de som målgruppe blev inddraget. Med de var ærgerlige over, at de ikke havde denne viden på forhånd, så de kunne have gjort sig mere umage. Den manglende information gjorde det også utydeligt for de unge, om deres erfaringer og deltagelse i interviewet ville få betydning; "Eller nu ved jeg selvfølgelig ikke, om vi fär nogen betydning for det. Men, men vi har $i$ hvert fald har provet den, inden at den bliver brugt af andre unge". Mere tydelighed om deltagelsen 
ville derfor både have haft betydning for de unges deltagelse og for deres oplevelse af at blive lyttet til.

Utydelighed kan også opstå undervejs i deltagelsesprocesser og være forbundet med tidsperspektiver. På en Rettighedsskole fortalte nogle elever, at de for nogle år tilbage var blevet inddraget i udviklingen af en ny legeplads. Men på interviewtidspunktet havde de helt opgivet nogensinde at se legepladsen realiseret: "De bygger bare cykelstativer og alt muligt til loererne. Men gården kommer ikke, ikke før vi går ud i hvert fald. Så vi har ingen gård." Eleverne sidder tilbage med en oplevelse af at have fået lov til at formulere deres ønsker, men at det ikke har haft nogen betydning. Selv om elevernes perspektiver i dette tilfælde faktisk er inddraget i skolegårdens udformning, som stadig er planlagt ombygget, så fremstår betydningen af deres deltagelse ikke tydelig for eleverne selv. Eksemplet understreger, hvordan børn og unges tidshorisonter kan være forskellige fra voksnes. Dels fordi unge, som eleverne i dette eksempel, oftere skifter mellem arenaer i deres hverdagsliv, eksempelvis fra folkeskole til ungdomsuddannelse, og derfor har et andet tidsligt perspektiv end de professionelle, lærerne, som generelt bliver i samme arena i længere tid. Men også fordi kortsigtede her-og-nu-oplevelser er særligt centrale for børn og unges tydelige oplevelse af deltagelsens forandringshorisont. Når børn og unge kan overskue tidshorisonten for de realiserede forandringer, fremstår deres deltagelse og deres adgang til at skabe konkrete og tydelige forandringer tydeligst for dem selv. Et eksempel på den tydelighed er til stede hos et medlem af Rettighedsrådet: "Ja altså, nu sidder vi og snakker om det, men det er [..] en meget rar følelse, når man faktisk går ud og gør noget ved tingene. Altså, for eksempel, så scetter man en ny pcere i." Dette konkrete eksempel omhandler en proces, hvor skolens mindre elever var utrygge i skolens kælder og Rettighedsrådet får sat mere lys op.

Den tydelige oplevelse af at deltagelse kan gøre en konkret forskel kan også, som i Mellemfolkeligt Samvirkes projekt 'En del af fællesskabet', have en mere overordnet karakter. Her fortæller en af de unge deltagere, hvordan hun oplevede at kunne gøre en forskel ved at få adgang til at holde oplæg ved et lokalpolitisk arrangement:

\footnotetext{
"Men øhh, så fik vi lov til, mig og [anden ung], der sidder derinde, at gå op og snakke om vores Ungefoellesskab, og hvad det har gjort for os, og hvorfor det kunne vcere en god idé at der skulle voere noget mere af det rundt omkring på Nørrebro."
}

Hvor deltagelsen altså både kan være helt skjult for børn og unge eller miste sin tydelighed undervejs i forløbet, så fremstår det med stor styrke i materialet hvor betydningsfuldt, det er for børn og unge, når de tydeligt erfarer, at de er deltagende og at deres deltagelse er forandringsskabende. Og som citatet ovenfor understreger, behøver deltagelsen ikke direkte at føre til de konkrete ønskede forandringer. Den kan også bestå i tydelige oplevelser af at blive lyttet til og taget alvorligt, samt oplevelsen af at perspektiver og ønsker tages med videre og kan påvirke forhold for dem selv og andre. 


\section{Et deltagelseskontinuum som orienteringspunkt i det pcedagogiske arbejde}

Litteraturen om børn og unges deltagelse er mangfoldig og mængden af anbefalinger, forståelser og opmærksomhedspunkter som kan bringes i spil, når børn og unges deltagelse skal fremmes, er overvældende. En første pointe med denne artikel er derfor at introducere en forholdsvis simpel model, både i sit grafiske udtryk og i sine niveauer, der samtidig, som eksemplerne ovenfor illustrerer, inviterer til kontinuerlige refleksioner i det pædagogiske arbejde.

Artiklens andet bidrag til det pædagogiske arbejde er at understrege, at de forskellige deltagelsesformer ikke er hierarkisk ordnede - der kan være gode pædagogiske begrundelser for at vælge forskellige deltagelsesformer til forskellige formål, for forskellige deltagere og i forskellige kontekster. Formålet med modellens venstre akse er desuden at tydeliggøre det pædagogiske arbejde med deltagelsesformer, hvor børn og unge ikke selv er til stede eller kan konsulteres. Det er deltagelsesformer, som benyttes meget hyppigt, eksempelvis i den pædagogiske planlægning og strategier og i det formelle sociale arbejde, og som sikrer, at børn og unges perspektiver bliver repræsenteret i fora, hvor de ikke har eller ønsker at have adgang.

Samtidig er det helt centralt at anerkende, at børn og unges deltagelse altid er relationel og derfor er betinget af, at det pædagogiske arbejde skal orientere sig mod at skabe ligeværdige dialoger, som øger børn og unges adgang til at kunne påvirke forhold af betydning for dem i deres hverdagsliv. En tredje pointe er derfor, at den manglende hierarkisering ikke må signalere, at man som professionel ikke behøver at arbejde med deltagelsesformerne yderst på den venstre akse. Derved ville vores kontinuum underminere både Hart's (1992) pointe om at undgå symbolsk deltagelse og Percy-Smith's (2006) fokus på ligeværdige dialoger. I langt det meste pædagogiske arbejde vil professionelle kun kunne repræsentere børn og unges perspektiver og præferencer, hvis de sammen med unge har indgået i processer midt for eller længere til højre på det præsenterede kontinuum. Hvis professionelle skal repræsentere børn og unges interesser i klubbens årsplaner, i ombygning af skolegården, i sagsbehandling eller i kommunale politikker, så er det en forudsætning at de unge, det drejer sig om, har haft mulighed for at ytre sig undervejs i processen.

Endelig, som en fjerde pointe, understreger artiklen vigtigheden af, at deltagelsen og dens forandringsskabende potentialer fremstår tydeligt for børn og unge. Kontinuummet tydeliggør og anerkender den deltagelse, hvor professionelle repræsenterer børn og unges perspektiver i fora, hvor de ikke har eller vil have adgang. Men ved at understrege den manglende tydelighed i denne deltagelsesform opfordrer modellen til, at det som et led i det pædagogiske arbejde tydeliggøres for børn og unge, når deres perspektiver spiller ind i planlægning og forandringsprocesser eller medvirker til nye forståelser og fremgangsmåder. Når unge konsulteres om mobbepolitikker, faglig undervisning eller i deres egne handleplaner, så er det 
afgørende for de unges oplevelse af deltagelse, at det tydeliggøres, hvordan deres indspil og ønsker er med til at forme de endelige politikker og planer. Som skitseret nedenfor kan tilbagemeldingerne også invitere til nye deltagelsesprocesser. For eksempel, hvis de unge ikke oplever, at deres perspektiver er blevet rigtigt forstået eller hvis der opstår nye perspektiver eller forandringsønsker i dialogen om, hvordan de unge har været med til at præge undervisning, handleplaner, mobbepolitikker osv. Oplevelsen af at have et aktørskab er nemlig, som Percy-Smith (2006) og Tofteng og Bladt (2019) skriver, med til styrke unges motivation, evner og orienteringer som aktive deltagere.

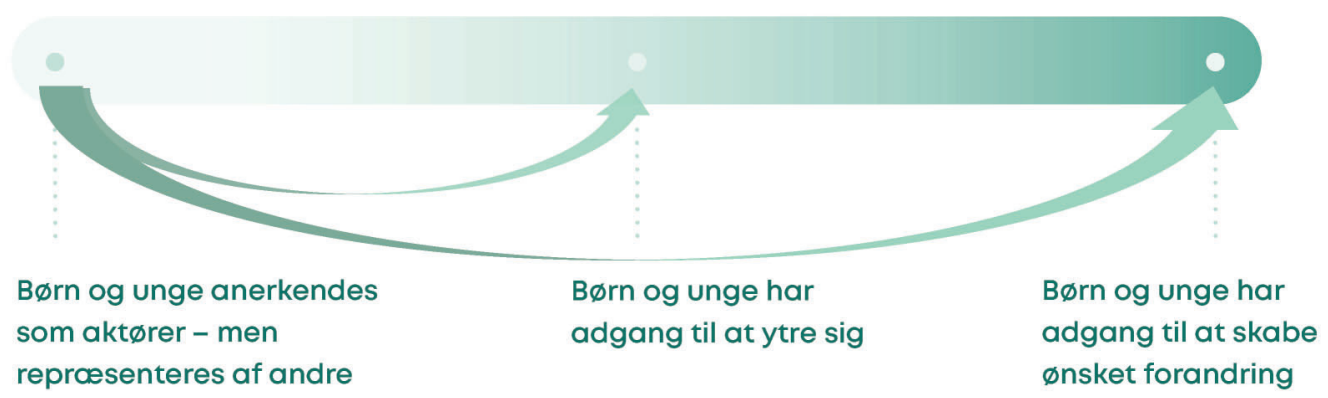

Figur 2 En visualisering af mulige dynamiske vekselvirkninger mellem forskellige deltagelsesformer

Tak til Anne Mette W. Nielsen for at være medskaber af det indledende grundlag for tankerne i denne artikel.

\section{Litteratur}

Arnstein, S. R. (1969). A Ladder of Citizen Participation. Journal of the American Institute of Planners 35 (4): 216-224. DOI:10.1080/01944366908977225.

Baraldi, C., \& Cockburn, T. (2018). Theorising childhood: Citizenship, rights and participation. Cham : Springer International Publishing.

Batsleer, J., Ehrensperger, K., Lüküslü, D., Osmanoğlu, B., Pais, A., Reutlinger, C., \& Zimmermann, D. (2017). Claiming spaces and struggling for recognition: Youth participation through local case studies. Partispace Comparative Case Study Report. DOI: 10.5281/zenodo.1064119

Bruselius-Jensen, M, Pitti, I \& Tisdall, E. K. M. (Eds.) (2021). Young people's participation In Europe - revisiting youth and inequality. Bristol: Policy Press.

Bruselius-Jensen, M \& Nielsen, A. M. W. (2020) Veje til deltagelse: Nye forståelser og tilgange til facilitering af børn og unges deltagelse. Aalborg: Aalborg Universitetsforlag.

Hart, R. A. (1992). Children's participation: From tokenism to citizenship. New York: Verso Books. James, A., Jenks, C., \& Prout, A. (1998). Theorizing childhood. Cambridge: Polity Press.

Jensen, B.B., \& Simovska, V. (2005). Involving students in learning and health promotion processes-clarifying why? what? and how? Promotion \& Education, 12(3-4), 150-156. DOI: $10.1177 / 10253823050120030114$

Nielsen, A. M. W., \& Bruselius-Jensen, M. (2021). Journey mapping as a method to make sense of participation. In M. Bruselius-Jensen, I. Pitti \& E. K. M. Tisdall (red.), Young people’s participation in Europe - revisiting youth and inequality (pp.335-355). Bristol: Policy Press. 
Mannion, G. (2007). Going spatial, going relational: Why "listening to children" and children's participation needs reframing. Discourse: studies in the cultural politics of education, 28(3), 405-420. DOI: 10.1080/01596300701458970

Percy Smith, B. (2006). From consultation to social learning in community participation with young people. Children, Youth and Environments, 16(2), 153-179.

Percy-Smith, B., \& Thomas, N. (2009). A handbook of children and young people's participation: Perspectives from theory and practice. Abingdon: Routledge.

Pohl, A., Batsleer, J., Loncle, P., \& Walther, A. (2019). Contested practices, power and pedagogies of young people in public spaces. I A. Walther, J. Batsleer, P. Loncle \& A. Pohl (red.), Young People and the Struggle for Participation: Contested Practices, Power and Pedagogies in Public Spaces (pp. 1 - 12). Abingdon: Routledge.

Tisdall, E. K. M., Hinton, R., Gadda, A. M., \& Butler, U. M. (2014). Introduction: Children and young people's participation in collective decision-making. I Children and young people's participation and its transformative potential: learning from across countries. (pp. 1-21). Basingstroke: Palgrave Macmillan.

Tofteng, D \& Bladt, M (2020) 'Upturned participation' and youth work: using a Critical Utopian Action Research approach to foster engagement, Educational Action Research, 28(1), 112-127. DOI: 10.1080/09650792.2019.1699843

Walsh, L., \& Black, R. (2018). Rethinking youth citizenship after the age of entitlement. Sydney: Bloomsbury Publishing.

Walther, A., Batsleer, J., Loncle, P., \& Pohl, A. (ed) (2019). Young people and the struggle for participation: Contested practices, power and pedagogies in public spaces. Routledge.

Warming, H. (2019). Børneperspektiv - en populær flydende betegner. Nordisk Tidsskrift for Pedagogikk Og Kritikk, (5). DOI: 10.23865/ntpk.v5.1424

Warming, H. (2011). Børneperspektiver: Børn som ligeværdige medspillere i socialt og pædagogisk arbejde. København: Akademisk forlag.

Wyness, M. (2019). Childhood and society. London: Red Globe Press. 